\title{
PENGEMBANGAN KONTEN E-LEARNING KONTEKSTUAL PADA MATA PELAJARAN PKN KELAS VIII DI SMP LABORATORIUM UNDIKSHA
}

\author{
N W. Winasih, I W. Santyasa, I W. Sukra Warpala \\ Program Teknologi Pembelajaran, Program Pascasarjana \\ Universitas Pendidikan Ganesha \\ Singaraja, Indonesia
}

\author{
e-mail: wayan.winasih@pasca.undiksha.ac.id \\ wayan.santyasa@pasca.undiksha.ac.id \\ sukra.warpala@pasca.undiksha.ac.id
}

\begin{abstract}
Abstrak
Penelitian ini dilakukan karena permasalahan keterbatasan media yang digunakan dalam proses pembelajaran. Penelitian ini bertujuan untuk (1) mendeskripsikan rancang bangun pengembangan konten e-learning kontekstual, (2) menguji validitas hasil pengembangan konten e-learning kontekstual PKn untuk siswa kelas VIII, dan (3) mengetahui efektivitas penggunaan pengembangan konten e-learning kontekstual terhadap hasil belajar PKn siswa kelas VIII. Jenis penelitian ini adalah penelitian pengembangan. Model yang digunakan adalah model pengembangan AM3PU3 (Santyasa, 2015) yang terdiri dari lima tahapan, yaitu (1) menentukan mata pelajaran yang menjadi objek pengembangan, (2) melakukan analisis kebutuhan, (3) mengembangkan draft (analisis tujuan dan karakteristik isi bidang studi, analisis sumber belajar, analisis karakteristik pebelajar, menetapkan indikator dan isi pembelajaran, menetapkan strategi pengorganisasian isi pembelajaran, menetapkan strategi penyampaian isi pembelajaran), (4) menyusun draft penegmbangan konten e-learning kontekstual, (5) melakukan uji ahli dan uji coba pengguna. Uji coba pengguna dalam penelitian pengembangan ini meliputi: 1) uji coba perorangan yang terdiri dari 3 (tiga) orang siswa, 2) uji coba kelompok kecil terdiri dari 9 (sembilan) orang, dan uji coba lapangan yang terdiri dari 30 (tiga puluh) siswa dan 1 (satu) orang pendidik. Hasil review dari ahli isi dan ahli media menyatakan bahwa konten e-learning kontekstual yang dikembangkan sudah sesuai. Kelayakan kualitas hasil validasi pengembangan konten $e-$ learning kontekstual terdiri dari: ahli isi mata pelajaran dengan kualifikasi sangat baik $(95,17 \%)$, ahli desain pembelajaran dengan kualifikasi sangat baik $(90,76 \%)$, ahli media pembelajaran dengan kualifikasi sangat baik $(91,11 \%)$, uji perorangan dengan kualifikasi sangat baik (91,54\%), uji kelompok kecil dengan kualifikasi baik (94.05\%), dan uji coba lapangan dengan kualifikasi sangat baik $(98,11 \%)$ dilihat dari guru mata pelajaran dan predikat baik $(88,83 \%)$ dilihat dari 30 (tiga puluh) siswa. Efektivitas penggunaan konten $e-$ learning kontekstual menunjukkan bahwa terdapatnya perbedaan yang signifikan dalam penerapan konten e-learning kontekstual terhadap hasil belajar PKn. Hasil perhitungan dengan menggunakan uji-t memberikan hasil signifikansi sebesar 0,001 yang lebih kecil dari 0,05 . Ini berarti terdapat perbedaan yang signifikan antara hasil belajar peserta didik sebelum belajar dengan bahan ajar konten e-learning kontekstual dan setelah belajar dengan bahan ajar konten e-learning kontekstual. Hasil belajar berdasarkan pencapaian nilai rata-rata posttest $(M=89,2000)(S D=5.67147)$ lebih tinggi dibandingkan nilai rata-rata pretest kategori rendah $(M=43,0667)(S D=9,28823)$. Hasil penelitian menunjukkan bahwa konten e-learning kontekstual mampu meningkatkan hasil belajar siswa.
\end{abstract}

Kata kunci: pengembangan, konten e-learning, kontekstual, mata pelajaran PKn . 


\section{Abstract}

This research is done because of the problem of media limitations used in the learning process. This study aims to (1) describe the design of content contextual e-learning development, (2) to examine the validity of the content development of the contextual elearning content of VIII students, and (3) to know the effectiveness of the use of contextual e-learning content development on the results learn PKN students of class VIII. This type of research is development research. The model used is a model of development AM3PU3 (Santyasa, 2015) which consists of five stages, namely (1) determine the subjects that become the object of development, (2) conduct a needs analysis, (3) develop draft (analysis of the purpose and characteristics of the contents of a field of study, analysis of learning resources, analysis of the characteristics of learners, establish indicators and learning content, define the strategy of organizing learning content, define the strategy of delivering learning content), (4) drafting penegmbangan e-learning content contextual, (5) perform expert testing and trial users. The user trials in this development study include: 1 ) individual trials of 3 (three) students, 2) small group trials consisting of 9 (nine) persons, and field trials of 30 (thirty) students and 1 (one) educator. The results of a review of content experts and media experts stated that content of contextual e-learning developed is appropriate. The quality of validation result of contextual e-learning content development consists of: highly qualified subject matter expert (95.17\%), highly qualified learning design expert $(90.76 \%)$, highly qualified instructional media ( $91,11 \%)$, individual test with excellent qualification (91,54\%), small group test with good qualification $(94.05 \%)$, and very good qualified field trial $(98,11 \%)$ seen from subject teacher and good predicate $(88.83 \%)$ seen from 30 (thirty) students. The effectiveness of the use of contextual e-learning content indicates that there is a significant difference in the application of contextual e-learning content to learning outcomes PKn. Result of calculation by using t-test give result of significance equal to 0,001 less than 0,05 . This means there is a significant difference between learning outcomes learners before learning by teaching content of contextual elearning content and after learning by teaching content of contextual e-learning content.The learning outcomes based on the achievement of posttest mean $(M=89,2000)(S D=$ $5.67147)$ were higher than the low average pretest category $(M=43,0667)(S D=9.28823)$. The results show that contextual e-learning content can improve student learning outcomes.

Keywords: development, e-learning content, contextual, subjects PKn

\section{PENDAHULUAN}

Pendidikan mempunyai peran sangat penting dalam meningkatkan kualitas sumber daya manusia dan upaya mewujudkan cita-cita bangsa Indonesia dalam mewujudkan kesejahteraan umum dan mencerdaskan khidupan bangsa. Berbagai usaha telah diterapkan oleh semua pihak baik oleh pemerintah maupun guru dalam upaya meningkatkan mutu pendidikan di Indonesia yang dianggap masih rendah. Dalam usaha mewujudkan upaya ini, pemerintah melakukan berbagai perombakan serta perubahan dengan melakukan perubahan dalam Kurikulum pendidikan yang baru yaitu Kurikulum 2013. Kurikulum 2013 merupakan implementasi dari Kurikulum terdahulu yaitu Kurikulum Tingkat Satuan Pendidikan (KTSP). Dalam upaya ini, diharapkan mutu pendidikan meningkat, sehingga siap bersaing dalam menghadapi era pasar bebas yang akan datang.

Mewujudkan pembelajaran yang memiliki mutu berkualitas, salah satu langkah yang dilakukan pemerintah adalah menetapkannya standar proses pembelajaran sebagaimana tertuang dalam peraturan menteri pendidikan dan kebudayaan (Permendikbud) Nomor 65 tahun 2013 yang mencakup karakteristik pembelajaran, perencanaan pembelajaran, pelaksanaan pembelajaran, penilaian hasil dan proses pembelajaran, dan 
pengawasan proses pembelajaran. Permendikbud ini menjadi pedoman bagi setiap guru untuk melaksanakan pembelajaran pada pendidikan dasar dan menengah.

Untuk dapat mencapai tujuan tersebut, maka dalam proses pembelajaran ada beberapa komponen yang harus diperhatikan seperti: guru, siswa, metode, media, sarana-prasarana dan kurikulum serta usaha lain yang berkenaan dengan peningkatan kualitas belajar tersebut. Pada era globalisasi seperti sekarang ini, dunia pendidikan sangat diharapkan mampu melahirkan pendidikan yang bermutu. Banyak faktor yang diperhatikan guna tercapainya mutu pendidikan yang maksimal. Salah satunya adalah pemilihan dan penggunaan strategi pembelajaran dalam proses pembelajaran.

Jika menginginkan pendidikan terlaksana secara teratur, berbagai elemen (komponen) yang terlibat dalam kegiatan pendidikan perlu dikenali. Dalam hal ini siswa memiliki peranan yang sangat penting dalam pendidikan, karena siswa adalah subyek dan objek pendidikan. Oleh karena itu keberadaan siswa dalam pendidikan sudah seharusnya diperlakukan dengan sebaik-baiknya dalam proses pembelajaran, sehingga tujuan pendidikan tercapai dengan efektif.

Pembelajaran yang efektif dan menarik merupakan langkah dalam upaya meningkatkan minat peserta didik terhadap proses pembelajaran. Langkah ini penting dilakukan sebagai inovasi terhadap proses pembelajaran yang bersifat monoton, yang diharapkan dapat meningkatkan aktivitas dan prestasi belajar peserta didik khususnya terkait dengan proses pembelajaran pendidikan kewarganegaraan atau disingkat menjadi PKn.

Mata pelajaran Pendidikan Kewarganegaraan (PKn) merupakan salah satu mata pelajaran yang harus dikuasai siswa di semua jenjang yang bertujuan untuk memfokuskan siswa pada pembentukan warga negara yang memahami dan mampu melaksanakan hak-hak kewajiban menjadi warga negara yang baik, cerdas, terampil, dan berkarakter yang diamanatkan dalam Pancasila dan UUD 1945. Mata pelajaran PKn memiliki tanggung jawab penting dalam mewujudkan tujuan pendidikan nasional.

Menurut Cholisin (2004:12) secara sederhana tujuan PKn adalah membentuk warga negara yang lebih baik (good citizen) dan mempersiapkannya untuk masa depan. Warga negara yang lebih baik diantaranya memiliki sikap dan perilaku yang sejalan dengan nilainilai pancasila dan nilai-nilai yang berlaku dalam kehidupan masyarakat. Selain itu PKn memiliki misi sebagai pendidikan demokrasi, pendidikan hukum, pendidikan moral/karakter.

Berdasarkan data yang diperoleh di SMP Laboratorium Undiksha, melalui wawancara yang dilakukan pada bulan Oktober 2016 dengan guru mata pelajaran PKn yang sudah memiliki pengalaman mengajar dan memiliki sertifikat pendidik, hasil yang di temukan bahwa nilai yang kurang memuaskan dari siswa pada mata pelajaran PKn, yaitu kurang dari nilai ketentuan yang telah ditentukan sekolah dengan nilai minimal kriteria ketuntasan minimal (KKM) 75. Menurut Rahmawati (2015), bahwa rendahnya prestasi belajar disebabkan oleh faktor intrinsik dan faktor ekstrinsik.

Permasalahan lain yang ditemukan di sekolah adalah guru belum mampu memanfaatkan secara maksimal fasilitas yang sudah ada di sekolah mulai dari komputer dan LCD proyektor. Permasalahan yang paling menonjol dalam proses pembelajaran adalah terbatasnya 
media pembelajaran yang menarik dan mampu memotivasi siswa dalam proses belajar mengajar, khususnya pada mata pelajaran PKn serta guru kurang inovatif dalam membuat sebuah media.

Penggunaan media juga masih sangat konvensional seperti bahan ajar berupa media visual cetak. Dalam proses pembelajaran hanya menggunakan sebuah buku sebagai satu-satunya sumber belajar, hal ini merupakan salah satu penyebab proses pembelajaran PKn terkesan kurang efektif dan variatif. Materi yang disajikan masih bersifat abstrak dan sulit untuk dimengerti oleh siswa. Hal ini diduga sangat berpengaruh terhadap minat dan motivasi siswa untuk belajar, selain itu guru di SMP Laboratorium Undiksha belum pernah menggunakan bahan ajar online seperti konten e-learning dalam proses pembelajaran.

Oleh sebab itu, guru perlu merancang sebuah bahan ajar online yang menarik bagi siswa serta dapat memotivasi minat belajar siswa. Faktor lain yang diduga mempengaruhi rendahnya hasil belajar siswa selain bahan ajar yang konvensional adalah penyajian materi yang kurang menghubungkan pengetahuan formal dengan pengalaman siswa sehari-hari, sehingga siswa berpendapat bahwa pelajaran $\mathrm{PKn}$ hanya dipelajari di sekolah saja tanpa ada hubungannya dengan kehidupan sehari-hari. Oleh sebab itu, perlu dikembangkan bahan ajar online yang inovatif seperti konten e-learning yang telah disesuaikan dengan karakteristik siswa.

Konten e-learning yang dikembangkan sendiri oleh pendidik dapat disesuaikan dengan karakteristik peserta didik. Selain lingkungan sosial, budaya, dan geografis, karakteristik peserta didik juga mencakup tahapan perkembangan peserta didik, kemampuan awal yang telah dikuasai, minat, latar belakang keluarga, dan lain-lain. Terdapat sejumlah materi pembelajaran yang seringkali sulit untuk dipahami oleh pesertadidik ataupun sulit dijelaskan oleh pendidik. Kesulitan tersebut dapat saja terjadi karena materi tersebut abstrak, rumit, dan asing.

Apabila materi pembelajaran juga bersifat abstrak, maka konten $e$ learning mampu membantu peserta didik menggambarkan sesuatu yang abstrak tersebut, misalnya dengan penggunaan gambar, foto, video dan yang lainnya. Demikian pula materi yang rumit, dapat dijelaskan dengan cara yang sederhana, sesuai dengan tingkat berfikir peserta didik, sehingga menjadi lebih mudah dipahami. Pendekatan kontekstual dapat membuat siswa mampu menghubungkan isi dari subjeksubjek akademik dengan konteks kehidupan keseharian mereka untuk menemukan makna.

Tujuannya mendorong siswa agar dapat menerapkannya dalam kehidupan mereka. Pendekatan kontekstual dapat diintegrasikan ke dalam konten e-learning dengan cara memasukkan komponen pendekatan kontekstual ke dalam konten $e$ learning hal ini seperti penelitian yang dilakukan oleh Pramono (2015) mengemukakan bahwa pembelajaran kontekstual atau yang disebut dengan Contextual Teaching and Learning (CTL) adalah konsep belajar yang membantu guru mengaitkan antara materi pembelajaran dengan situasi dunia nyata siswa, dan mendorong siswa membentuk hubungan antara pengetahuan yang dimilikinya dengan penerapan kehidupan mereka sehari-hari.

Berdasarkan perkembangan teknologi piranti pembelajaran tersajikan dalam berbagai tindakan seperti seperti perpustakaan online, e-learning, pembuatan CD interaktif, 
virtual university dan lain sebagainya. Sistem ini memanfaatkan media komputer dan jaringan sebagai sistem pembelajarannya. Proses pembelajaran yang sebelumnya menggunakan tatap muka di dalam kelas diperluas jangkauannya dengan menggunakan sistem $e$ learning atau seiring dengan perkembangan teknologi dikenalah istilah pendidikan jarak jauh. Menurut Undang-Undang 20 Tahun 2003 tentang Sistim Pendidikan Nasional (SISDIKNAS), yang dimaksud dengan pendidikan jarak jauh adalah "pendidikan yang pesertanya didiknya terpisah dari pendidik dan pembelajarannya menggunakan berbagai sumber belajar melalui teknologi komunikasi, informasi dan media lainnya".

Konten e-learning dengan pendekatan kontekstual adalah konten e-learning yang komponen kegiatan belajarnya dikaitkan dengan objek-objek atau kejadian-kejadian aktual di dunia nyata yang akrab dengan kehidupan peserta didik. Pembelajaran kontekstual berkaitan dengan adanya tuntutan akan kemampuan peserta didik dalam menggunakan konsep-konsep dan prinsip-prinsip yang dipelajari untuk memecahkan masalah-masalah dunia nyata yang terkait dengan kehidupan sehari-hari. E-learning merupakan pembelajaran yang disusun dengan tujuan menggunakan sistem elektronik atau komputer sehingga mampu mendukung proses pembelajaran.

Menurut Sharaf (2015) elearning adalah istilah inklusif yang menggambarkan teknologi pendidikan yang secara elektronik atau teknologi mendukung belajar dan mengajar. Selain itu dengan diimplementasikannya e-learning guru tidak perlu memberikan materi secara berulang-ulang karena materi sudah disajikan melalui konten $e$ learning dengan pendekatan kontekstual. Konten e-learning sangat dibutuhkan di sekolah karena sekolah merasa kesulitan dalam melakukan pemutakhiran bahanbahan belajar yang menjadi tanggung jawabnya sesuai dengan tuntutan perkembangan keilmuan yang mutakhir.

Adanya fasilitas yang mampu dari segi SDM dan saran maka konten e-learning ini cocok untuk dikembangkan. Selain itu, dampak yang dirasakan jika tidak adanya konten e-leraning ini informasiinformasi yang dibutuhkan oleh peserta didik sulit untuk disampaikan. Jadi, dengan konten e-learning ini mampu memudahkan peserta didik dalam mengakses informasi yang dibutuhkan. Dengan kehadiran konten e-learning ini sungguh memberi efek dampak positif, seiring dengan berkembangnya era globalisasi. Untuk menciptakan konten e-learning yang menarik dan menyenangkan bagi siswa masih diperlukan berbagai terobosan dalam mengembangkan inovasi pembelajaran dan pemenuhan sarana dan prasarana pendidikan yang memadai.

Keberhasilan

proses

pembelajaran merupakan hal utama yang didambakan dalam melaksanakan pendidikan di sekolah. Secara sederhana dapat dikatakan bahwa semua pembelajaran dilakukan dengan memanfaatkan teknologi internet dan selama proses belajar terjadi oleh yang mengikutinya, maka kegiatan itu dapat disebut sebagai pembelajaran online. Kemudian, yang ditawarkan oleh teknologi ini adalah kecepatan dan tidak terbatasnya tempat dan waktu untuk mengakses informasi. Kegiatan belajar dapat dengan mudah dilakukan oleh peserta didik kapan saja dan dimana saja dirasakan aman oleh peserta didik tersebut. 
Batas ruang, jarak dan waktu tidak lagi menjadi masalah yang rumit untuk dipecahkan. Berdasarkan pemikiran dan pertimbangan permasalahan, peneliti memandang perlu mengembangkan konten $e$ learning kontekstual pada mata pelajaran PKn kelas VIII di SMP laboratorium Undiksha sebagai salah satu cara memecahkan masalah pembelajaran.

Berdasarkan pemikiran dan pertimbangan permasalahan tersebut, dipandang perlu mengembangkan konten e-learning kontekstual pada mata pelajaran PKn kelas VIII di SMP laboratorium Undiksha sebagai salah satu cara memecahkan masalah pembelajaran. Berdasarkan latar belakang masalah tersebut, penelitian ini memusatkan perhatian untuk menjawab 3 (tiga) pertanyaan penelitian. 1) Bagaimanakah rancang bangun pengembangan konten $e$ learning kontekstual pada mata pelajaran PKn kelas VIII di SMP laboratorium Undiksha?; 2) Bagaimanakah validitas hasil pengembangan konten e-learning kontekstual pada mata pelajaran PKn kelas VIII di SMP laboratorium Undiksha, menurut review para ahli, uji coba perorangan, uji coba kelompok kecil dan uji coba lapangan?; 3) Bagaimanakah efektivitas konten e-learning kontekstual pada mata pelajaran PKn kelas VIII di SMP laboratorium Undiksha?

\section{METODE}

Pengembangan konten e-
learning ini
menggunakan pontekstual pengembangan
AM3PU3 (Santyasa, 2015). Alasan
digunakannya model ini adalah
karena tahapan-tahapan di dalam
model AM3PU3 ini tersusun secara
sistematis sehingga lebih mudah
dipahami.

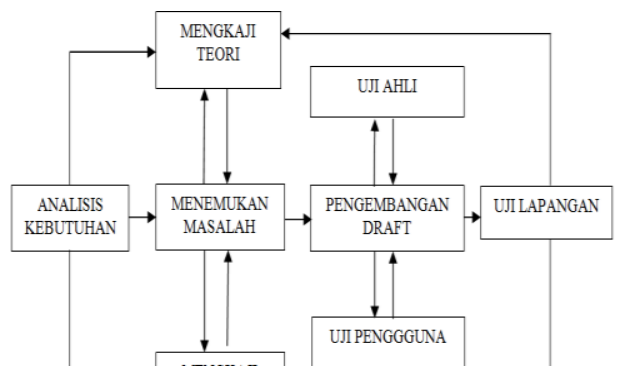

Gambar 1. Desain Pengembangan Model AM3PU3 (Santyasa, 2015).

Berdasarkan Gambar di atas, tampak bahwa model AM3PU3 dimulai dari Analisis Kebutuhan. Proses ini dilaksanakan dalam rangka memperoleh data pendahuluan terkait dengan keberadaan produk yang akan dikembangkan. Dalam hal ini, produk yang ingin dikembangkan memang belum ditemukan keberadaannya dalam praksis pendidikan, khususnya di SMP laboratorium Undiksha.

Setelah menganalisis kebutuhan, tahap berikutnya yaitu menemukan masalah, mengkaji teori, dan mengkaji data empiris, yang mana teori-teori dan data empiris yang dikaji adalah yang terkait dengan masalah yang ditemukan serta dapat mendukung pemecahan masalah. tersebut. Setelah tahapan AM3, tahap berikutnya. adalah pengembangan draft, yang mana draft yang dikembangkan akan divalidasi dengan Uji Ahli serta Uji Pengguna yang mana hasil uji ahli dan Uji penggunaan akan digunakan untuk penyempurnaan draft sebelum diadakan uji lapangan. Hasil uji lapangan tersebut akhirnya akan disinkronkan dengan kajian teori serta kajian data empiris yang digunakan.

Adapun tahapan-tahapan model AM3PU3 dapat disajikan dalam gambar 2. 

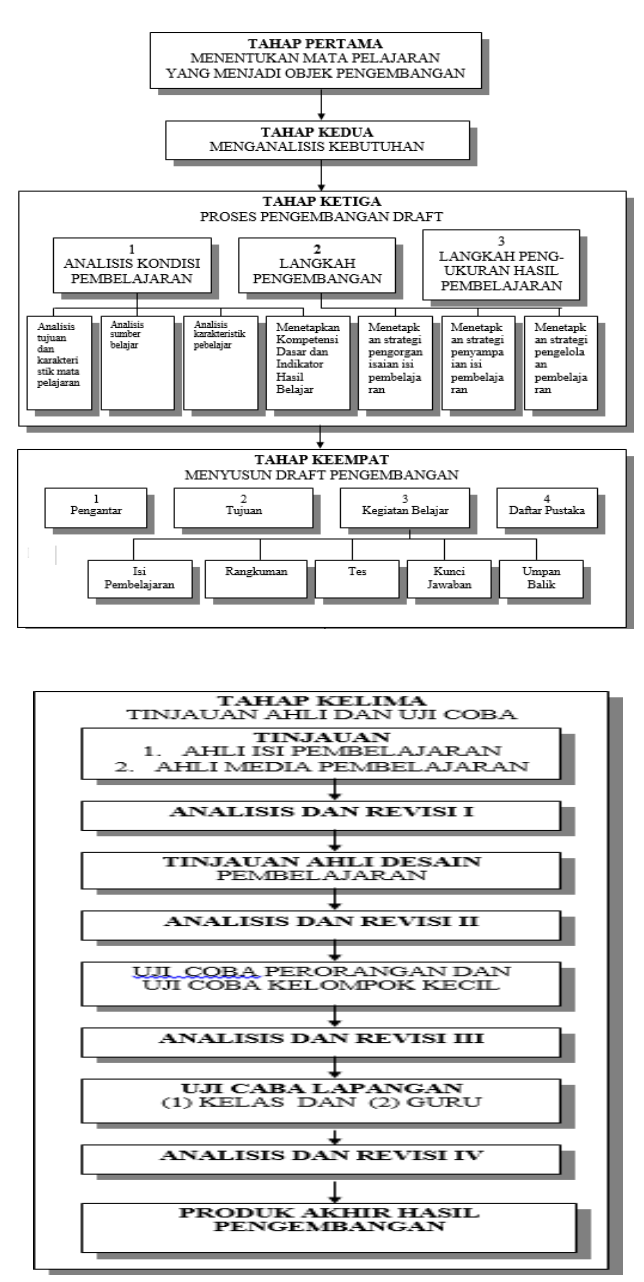

Gambar 2 Tahapan-tahapan operasional Pengembangan Draft (Santyasa, 2015).

Tahap pertama dalam pengembangan konten e-learning kontekstual ini adalah menentukan mata pelajaran yang menjadi objek pengembangan. Tahap kedua dalam pengembangan konten e-learning kontekstual ini adalah melakukan analisis kebutuhan. Pada tahap ini merupakan proses yang dilakukan untuk mengembangkan draft (Analisis Tujuan dan Karakteristik Isi Bidang Studi, Analisis Sumber Belajar, Analisis Karakteristik Pebelajar, Menetapkan Indikator dan Isi Pembelajaran, Menetapkan Strategi Pengorganisasian Isi Pembelajaran, Menetapkan Strategi Penyampaian Isi Pembelajaran), tahap keempat adalah menyusun draft penegmbangan konten $e$ learning kontekstual, Setelah draft konten e-learning kontekstual selesai dibuat, maka tahap kelima

yang perlu dilakukan adalah melakukan tinjauan ahli dan uji coba produk. Uji coba produk dalam penelitian pengembangan ini meliputi: I) rancangan uji coba,

2) subyek uji coba, 3) jenis data,

4) instrumen pengumpulan data, dan 5) teknik analisis data.

Uji coba produk dalam penelitian pengembangan ini meliputi 1) rancangan uji coba; 2) subyek uji coba; 3) jenis data; 4) instrumen pengumpulan data; dan 5) teknik analisis data. Uji coba dilakukan dalam beberapa tahap yakni a) review oleh ahli isi; b) ahli media; c) review ahli desain pembelajaran; d) uji perorangan; e) uji kelompok kecil; dan 6) uji lapangan. Uji coba produk di review oleh, 1) ahli isi, ahli media dan ahli desain; 2) Uji coba perorangan terdiri dari tiga orang peserta didik terdiri dari satu orang yang memiliki prestasi belajar tinggi, satu orang yang memiliki prestasi sedang, dan satu orang yang memiliki prestasi rendah pada mata pelajaran PKn. 3) uji coba kelompok kecil terdiri dari sembilan peserta didik terdiri dari tiga orang yang memiliki prestasi belajar tinggi, tiga orang yang memiliki prestasi sedang, dan tiga orang yang memiliki prestasi rendah pada mata pelajaran $\mathrm{PKn}$; 4) Uji coba lapangan diambil sampel satu kelas VIII SMP Laboratorium Undiksha terdiri dari 30 orang peserta didik dan 1 orang pendidik mata pelajaran PKn. Instrumen yang digunakan untuk mengumpulkan data dalam penelitian pengembangan ini adalah kuesioner dan tes hasil belajar. Kuesioner digunakan untuk mengumpulkan hasil review para ahli, uji coba perorangan, uji coba kelompok kecil, pendidik dan peserta didik uji lapangan. Tes hasil belajar digunakan untuk mengumpulkan hasil belajar peserta didik sebelum dan sesudah menggunakan konten e-learning kontekstual pada uji lapangan.

Penelitian ini menggunakan 
tiga metode analisis data, yaitu 1) analisis deskriptif kualitatif, 2) analisis deskriptif kuantitatif, dan 3) analisis statistik inferensial. Analisis deskriptif kualitatif digunakan untuk mengolah data hasil uji coba dari ahli isi, ahli desain, ahli media, peserta didik perseorangan, peserta didik kelompok kecil peserta didik uji lapangan dan pendidik, sedangkan analisis deskriptif kuantitatif digunakan untuk mengolah data yang diperoleh dari angket dalam bentuk deskriptif persentase.

Statistik inferensial berupa ujit digunakan menganalisis perbedaan skor pretest dan posttest yang diperoleh saat uji coba lapangan. Data yang diolah pada uji lapangan adalah data hasil pretest dan posttest. Pretest diberikan kepada peserta didik sebelum pembelajaran dengan konten e-learning kontekstual diberikan dan posttest diberikan kepada peserta didik setelah pembelajaran dengan konten e-learning kontekstual selesai diberikan. Hipotesis penelitian diuji dengan uji-t (paired samples $t$-test). Ketentuannya adalah sebagai berikut: 1) jika probabilitasnya $>0,05$ maka $\mathrm{H}_{0}$ diterima, dan 2) jika probabilitasnya $<0,05$ maka $\mathrm{H}_{0}$ ditolak. Untuk memaknai keefektifan peningkatan hasil belajar, maka skor rata-rata posttest dicocokkan dengan konversi kualifikasi hasil belajar SMP Laboratorium Undiksha.

\section{HASIL DAN PEMBAHASAN}

Hasil pengembangan adalah berupa konten e-learning kontekstual selama satu semester. Hasil review ahli isi dan ahli media menyatakan bahwa konten e-learning kontekstual yang dikembangkan sudah sesuai. Hasil tanggapan ahli desain pembelajaran memperlihatkan bahwa ahli desain memberikan tanggapan sangat baik dengan persentase $90,76 \%$. Hasil persentase keseluruhan peserta didik untuk uji siswa perorangan sebesar $93,93 \%$ terletak pada kualifikasi sangat baik. Hasil persentase keseluruhan peserta didik untuk uji kelompok kecil sebesar $94,05 \%$ terletak pada kualifikasi sangat baik. Hasil tanggapan pendidik untuk uji lapangan memperlihatkan bahwa pendidik memberikan tanggapan sangat baik dengan persentase 98,18\%. Hasil tanggapan peserta didik untuk uji lapangan memperlihatkan bahwa peserta didik memberikan tanggapan sangat baik sebanyak $33,33 \%$, baik sebanyak $66,67 \%$ dan sebanyak $0 \%$ untuk kategori cukup, kurang dan sangat kurang. Hasil persentase keseluruhan peserta didik untuk uji lapangan sebesar $86,42 \%$ terletak pada kualifikasi baik Hasilperhitungan dengan menggunakan uji-t memberikan hasil sig sebesar 0,001 yang lebih kecil dari 0,05 . Hal ini menunjukkan bahwa $\mathrm{HO}$ ditolak dan $\mathrm{H} 1$ diterima. Dapat dikatakan bahwa terdapat perbedaan nilai rata- rata pretest dan posttest peserta didik. Nilai rata-rata pretest (Mean=43,0667) lebih tinggi dibandingkan nilai rata-rata posttest (Mean $=89,2000)$. Ini berarti terdapat perbedaan yang signifikan hasil belajar siswa antara sebelum belajar dengan konten $e$ learning kontekstual dan setelah belajar dengan

konten elearningkontekstual. Sehingga konten e- learning kontekstual efektif meningkatkan hasil belajar siswa. Penggunaan konten $e$ learning kontekstual dalam pembelajaran PKn dapat membuat pembelajaran PKn lebih bermakna. Pendekatan kontekstual adalah kegiatan pembelajaran yang memfasilitasi kegiatan siswa untuk mencari, mengolah, dan menemukan pengalaman bersifat konkrit atau nyata, sehingga penggunaan konten e-learning kontekstual dalam pembelajaran maka siswa dapat menghubungkan materi dengan kehidupan mereka sehari-hari dan diharapkan siswa akan dapat lebih mudah memahami materi pelajaran 
dan dapat memahami masalah yang dihadapi sekaligus memecahkan masalah tersebut dengan menerapkan materi yang telah diperoleh di sekolah. Berdasarkan uraian tentang hasil penelitian, secara rinci terdapat sub bab pembahasan dipaparkan pembahasan terhadap, (1) rancang bangun konten e-learning kontekstual, (2) hasil uji validitas konten e-learning kontekstual, dan (3) hasil uji efektivitas konten e-learning kontekstual.

Adapun pembahasannya sebagai berikut.

Pertama Rancang bangun konten e-learning kontekstual telah dilakukan sesuai dengan metode pencatatan dokumen yaitu mencatat tahap-tahap yang telah dilakukan sesuai dengan prosedur pengembangan. Pengembangan konten e-learning kontekstual sangat perlu mengetahui alur navigasi dari produk yang dikembangkan. Oleh karena itu, Pada tahap ini menghasilkan flowchart dan storyboard. Flowchart merupakan gambaran alur kerja dari konten $e$ learning kontekstual, sedangkan desain storyboard mencangkup tata letak, ukuran huruf, pewarnaan, video.

Kedua Sebelum digunakan pada proses pembelajaran, produk yang dikembangkan harus melalui tahap validasi yang meliputi review ahli dan uji coba produk.

Ketiga Uji efektivitas digunakan untuk mengetahui tingkat efektivitas penggunaan produk konten e-learning kontekstual terhadap hasil belajar pada siswa kelas VIII di SMP Laboratorium Undiksha. Keefektifan konten elearning kontekstual diketahui dari adanya perbedaan nilai siswa sebelum menggunakan konten $e$ learning kontekstual dengan nilai siswa setelah menggunakan konten e-learning kontekstual.
Hasil tes menunjukkan ratarata pretest berada pada kualifikasi cukup itu dikarenakan dalam proses pembelajaran pendidik belum menggunakan media dan hanya menggunakan metode ceramah saja, sedangkan hasil tes menunjukkan bahwa rata-rata posttest berada pada kualifikasi sangat baik, itu dikarenaka dalam proses pembelajaran pendidik sudah menggunakan konten $e$ learning kontekstual. Peningkatan rata-rata nilai siswa ini juga dapat dilihat berdasarkan jawaban-jawaban siswa saat pemberian tes. Sebagian besar jawaban siswa yang salah saat pretest, benar saat posttest. Hal ini disebabkan karena, konten $e$ learning kontekstual ini digunakan saat proses pembelajaran, sehingga siswa lebih antusias untuk belajar. Selain di sekolah, siswa juga dapat menggunakan dan mempelajari media ini di rumah. Siswa pun dapat lebih memahami materi yang diajarkan, sehingga akan berpengaruh pada peningkatan hasil belajarnya.

Hal ini sejalan dengan penelitian yang dilakukan Bakri \& Dewi (2017) menunjukkan bahwa melalui e-learning materi pembelajaran dapat diakses kapan saja dan dari mana saja, di samping itu materi yang dapat diperkaya dengan berbagai sumber belajar termasuk multimedia dengan cepat dapat diperbaharui oleh peserta didik. Meningkatnya hasil belajar siswa disebabkan konten e-learning kontekstual memberikan kemudahan kepada siswa dalam memahami materi dibandingkan dengan membaca buku saja. Dalam konten e-learning kontekstual, materi dapat disajikanmenggunakan gambar, dan video serta berbagai contoh-contoh yang menarik. Sehingga materi yang bersifat abstrak akan lebih mudah dipahami.

Setelah dilakukan

penghitungan secara manual 
diperoleh hasil uji-t dengan taraf signifikansi $5 \%(\alpha=0,05)$. Nilai ratarata skor pretest didapatkan sebesar 43,0667, posttest sebesar 89,2000, dan nilai sig $=0,001$. Dengan demikian nilai sig $0,001<0,05$, sehingga $\mathrm{H} 0$ ditolak dan $\mathrm{H} 1$ diterima. Dengan kata lain terdapat perbedaan nilai rata-rata hasil belajar peserta didik setelah menggunakan konten $e$ learning kontekstual dengan peserta didik sebelum menggunakan konten e-learning kontekstual. Dilihat dari konversi hasil belajar di SMP Laboratorium Undiksha, nilai ratarata posttest peserta didik 89,2000 berada pada kualifikasi Baik, dan berada di atas nilai KKM mata pelajaran PKn sebesar 67. Melihat nilai rarata atau mean posttest yang lebih besar dari nilai rerata atau mean pretest, dapat dikatakan bahwa konten e-learning kontekstual dapat meningkatkan hasil belajar PKn siswa.

Hal ini juga didukung penelian yang dilakukan oleh Meliana dan Setya (2017) menyatakan bahwa media pembelajaran e-learning berbasis schoology ini mendapat respon yang sangat baik dari siswa sebagai media pembelajaran. Terdapat faktor yang menyebabkan nilai posttest lebih besar dibandingkan nilai pretest yaitu, a) dengan adanya media konten elearning kontekstual dapat meningkatkan motivasi, dan minat belajar siswa, sehingga siswa dapat menjelaskan contoh-contoh yang terjadi pada kehidupan sehari-hari melalui video dan gamabar yang terdapat pada konten e-learning $\mathrm{b}$ ) siswa dapat belajar dimana saja tanpa terbatas ruang dan waktu, sehingga dengan adanya konten elearning ini memudahkan siswa dalam belajar, c) siswa juga dapat mengukur kemampuan mereka melalui quiz yang terdapat pada konten e-learning kontekstual, sehingga siswa lebih siap saat diberikan test di kelas. Dari hasil tersebut membuktikan bahwa terdapat peningkatan hasil belajar yang signifikan antara siswa yang menggunakan pengembangan konten e-learning kontekstual pada mata pelajaran $\mathrm{PKn}$ dibandingkan hanya menggunakan metode ceramah saja.

\section{PENUTUP}

Model AM3PU3 adalah model eleborasi karena didasari oleh kajian teoretik model elaborasi yang terdiri dari delapan langkah yakni; 1) analisis kebutuhan; 2) menemukan masalah; 3) mengkaji teori; 4) mengkaji data empiris; 5) pengembangan draft; 6) uji ahli; 7) uji pengguna; dan 8) uji lapangan.

Ahli isi dan media pembelajaran memberikan tanggapan bahwa konten e-learning kontekstual ini sudah sesuai dan layak untuk digunakan dalam pembelajaran. Ahli desain pembelajaran memberikan tanggapan bahwa konten e-learning kontekstual ini baik dan layak untuk digunakan dalam pembelajaran.

Peserta didik dalam uji perorangan memberikan tanggapan bahwa konten e-learning kontekstual ini sangat baik. Peserta didik dalam uji kelompok kecil memberikan tanggapan bahwa konten e-learning kontekstual ini sangat baik. Pada uji lapangan untuk pendidik memberikan tanggapan bahwa konten e-learning kontekstual ini sangat baik. Nilai rata-rata posttest secara signifikan lebih tinggi dibandingkan dengan nilai rata-rata pretest. Ini berarti terdapat perbedaan yang signifikan antara hasil belajar peserta didik sebelum belajar dengan bahan ajar konten $e$ learning kontekstual dan setelah belajar dengan bahan ajar konten $e$ learning kontekstual. Hasil penelitian menunjukkan bahwa konten elearning kontekstual mampu 
meningkatkan hasil belajar siswa. Konten e-learning kontekstual yang dikembangkan sudah teruji kelayakan dan kefektifannya.

\section{DAFTAR RUJUKAN}

Bakri, F \& Dewi, M. (2017). Pengembangan perangkat elearning untuk matakuliah fisika dasar II menggunakan LMS chamilo. Jurnal Wahana Pendidikan Fisika. 2 (1). 2530. Tersedia pada: http://ejou rnal.upi.edu/index.php/Wapfi /article/download /4868/pdf_1. Diakses pada tanggal 25 Oktober 2017

Cholisin. (2004). Pendidikan kewarganegaraan (civic education). Yogyakarta: Fakultas IImu Sosial dan Ekonomi UNY.

Meliana, P. S. D \& Setya, C. W. (2017). Pengembangan elearning berbasis schoology untuk meningkatkan hasil belajar siswa pada mata pelajaran jaringan dasar kelas X TKJ. Jurnal IT-EDU. 02 (01). 136-140. Tersedia pada: jurnalmah asiswa.unesa.ac.id/article/25 53 9/118/article.pd f. Diakses pada tanggal 25 Oktober 2017

Permendikbud. (2013). Peraturan menteri pendidikan dan kebudayaan republik Indonesia nomor 65 tahun 2013 tentang standar proses pendidikan dasar dan menengah. Tersedia pada: http://bsnp-indonesia.Org/id/ wp-content/uploads/20 09/06 /03.-A.-Salinan-Permendikbu d-No.-65-th-2013-ttg-Standar -Pro ses.pdf. Diakses pada 25 September 2016.

Pramono, N. W. E. (2015). Pembelajaran KonteKstual dalam membangkitkan kepemimpinan transformative. Jurnal Penelitian. 9(2). 233-254. Tersedia pada: http://jour nal.stainkudus.ac.id/index.p hp/jurnalPenelitian/article/do wnload/1320/1164. Diakses pada 25 September 2016.

Rahmawati, R., Sudiyanto., \& Sri, S. (2015). Keefektifan penerapan e-learning-quipper school pada pembelajaran akuntansi di sma negeri 2 surakarta. Jurnal tata arta UNS. 1(1): 1-12. Tersedia pada: http://www.Jurnal.fkip. uns.ac.id/index.php/tataarta/ article /download/6206/4291. Diakses 25 September 2016.

Santyasa, I. W. (2015). Pendekatan kuantitatif dalam penelitian MIPA dan pendidikan MIPA. Makalah (tidak diterbitkan), disajikan dalam Seminar akademik fakultas MIPA Undiksha, 25 Nopember 2015 di Singaraja

Sharaf, A. A. (2015). The future of elearning and tools in higher education. International Journal of Advances in Computer Science and Technology. 4(1): 1-5. Tersedia pada: http://www .warse.org/pdfs/2014/ijacst0 1412015.pdf. Diakses pada 25 September 2016. 